\title{
Smith W. Brookhart and Russia
}

Ronald F. Briley

THE RESULTS OF THE SENATORIAL elections of 1922 in the Midwest shocked the nation. The farmers of this region, in the midst of an agricultural depression, had selected proponents of radical agricultural legislation to be their spokesmen: Lynn Frazier of North Dakota, Robert Howell of Nebraska, Henrik Shipstead of Minnesota, and Smith Wildman Brookhart of Iowa. The legislative activities of these men constituted an attempt to confront the farm problems raised by the agricultural depression of $1920 .^{1}$

Frazier, Howell, Shipstead, and Brookhart have generally been characterized as isolationists. Historians have argued that the Midwest is geographically isolated from foreign affairs, economically self-sufficient, a Republican area which has disapproved of the foreign interventions of Democratic presidents, and a section dominated by European ethnic groups which wanted to avoid entanglements in the difficulties of their former home lands. ${ }^{2}$

Wayne S. Cole, in his biography of North Dakota Senator Gerald P. Nye, argues that Nye's isolationist views stemmed from his allegiance to the forces of agrarianism. In domestic politics, Nye was opposed to business, industrial, and financial interests, which he perceived as being detrimental to agricultural interests.

'Ronald F. Briley, "Challenge to Normalcy: Four Midwestern Political Mavericks, 1922-1924" (unpublished M.A. Thesis, West Texas State University, 1972).

${ }^{2}$ Ray A. Billington, "The Origins of Middle Western Isolationism," Political Science Quarterly. LX (March, 1945), 44-63; Samuel Lubell, The Future of American Politics (New York, 1951), 131-156. 
He supported neutrality legislation because international conflicts such as World War I had benefited business, industry, and finance, while harming agriculture. ${ }^{3}$ Another historian, Selig Adler, also has commented upon the importance of the American agrarian tradition in shaping a policy of isolation. Adler contends that the American reluctance to become involved in foreign affairs is in part due to a feeling of superiority, based upon the belief that the world is dependent upon American wheat supplies. ${ }^{4}$

If the agrarian sector has traditionally produced isolationist attitudes, then it seems logical that the midwestern representatives elected in 1922 could be assigned to the isolationist ranks. Nevertheless, a review of the senatorial careers of Frazier, Howell, Shipstead, and Brookhart reveals that all of these men expressed some interest in foreign affairs. Brookhart, especially, is an exception to the assumption that agrarian-oriented leaders of the Midwest wished to remain aloof from foreign affairs. ${ }^{5}$ The activities of Smith Brookhart suggest that a policy of internationalism can exist without formal political and legal attachments.

In 1923 Brookhart traveled to Europe. He returned from his journey impressed by what he had seen in Russia and the Scandinavian nations. Acting upon these favorable impressions, he launched a campaign for American recognition of Russia. Brookhart openly expressed his interest in Russia to his Iowa constituency, and was not subsequently censured by the voters of that state. Brookhart's interest in Russia raises some important questions regarding the assumption that midwestern agrarianism unequivocally supported isolationism in the 1920s.

Smith W. Brookhart was born in Scotland County, Missouri, on February 2, 1869, in a log cabin, a very auspicious background for a politician whose appeal would be to the farmers of a depressed agricultural area. ${ }^{6}$ In 1879 the Brookhart family moved to

\footnotetext{
${ }^{3}$ Wayne S. Cole, Senator Gerald P. Nye and American Foreign Relations (Minneapolis, 1962), 4-13.

${ }^{4}$ Selig Adler, The Isolationist Impulse: Its Twentieth Century Reaction (New York, 1957), 22.

${ }^{5}$ Historians have often defined isolationism narrowly, construing it to mean a freedom from binding political commitments. Selig Adler, Uncertain Giant. 1921-1941: American Foreign Policy Between the Wars (New York, 1965), 80; Robert James Maddox, "Another Look at the Legend of Isolationism in the 1920's," Mid-America, LIII (Jan., 1971), 37.

${ }^{6}$ For a good background of Smith Brookhart's early years see Ray S. John-
} 


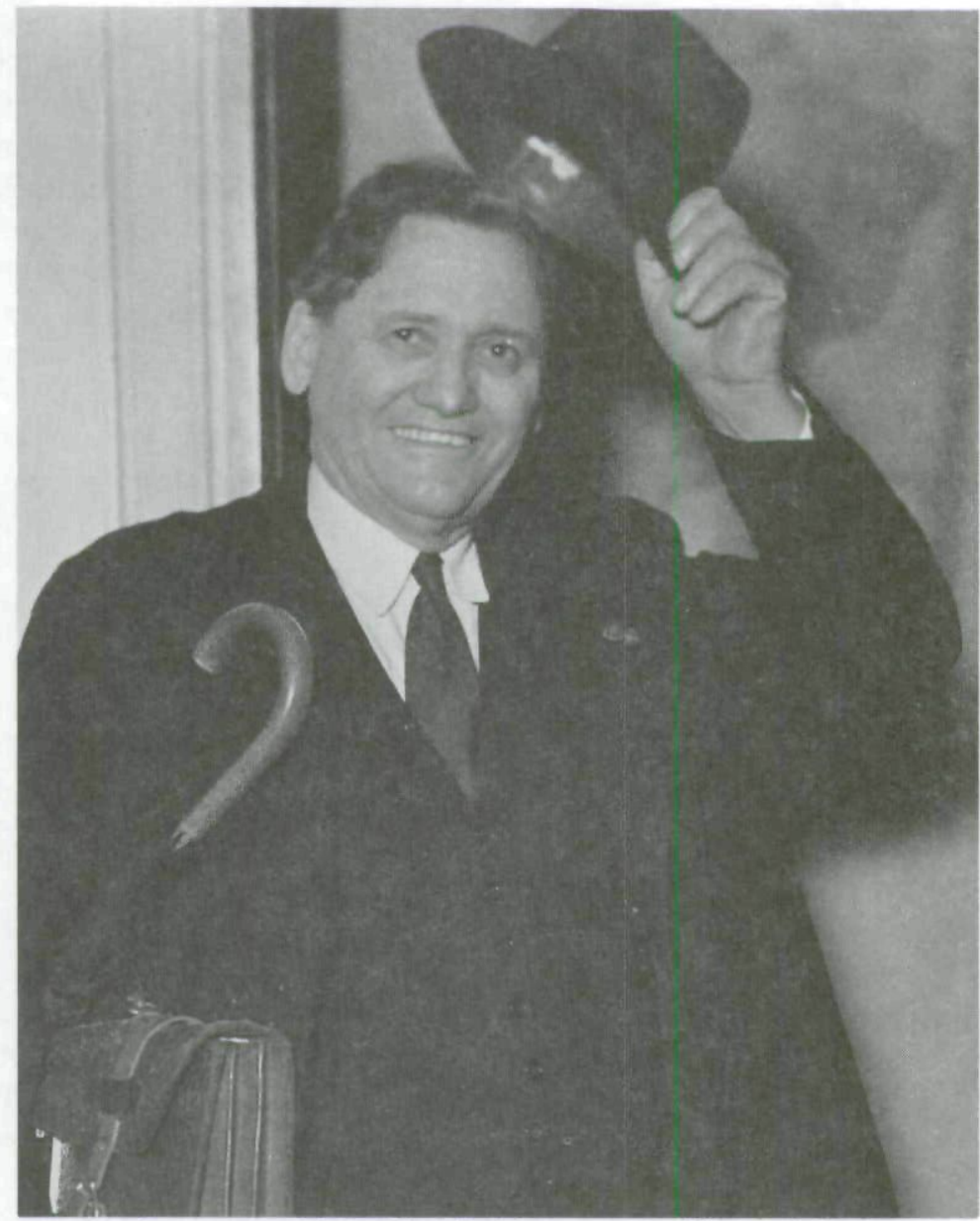

Photograph courtesy of Iowa Historical Department, Historical Museum and Smith W. Brookhart Archives Division

Iowa where their young son, Smith, would later fight his political battles. Brookhart attended Iowa schools until his graduation from Southern Iowa Normal School in 1889, when he went into the teaching field. Tiring of teaching, he took and passed the state bar exam in 1892 .

ston, "Smith Wildman Brookhart: Iowa's Last Populist" (unpublished M.A. Thesis, State University of Iowa, 1964). 
Like many of his counterparts, Brookhart's interest in law soon led into politics. Iowa still identified with the legacy of Abraham Lincoln and the Civil War, and a large number of G.A.R. veterans resided in the state. Brookhart affiliated with the Republican party. Meanwhile, he continued his law practice in Washington, Iowa, in a fashion that might only be termed fairly successful. Indeed, his detractors would soon claim that Brookhart's law practice or more accurately, the lack of it, was the reason he turned to politics as a career.?

For whatever reason, it was obvious that Smith Brookhart did have a strong interest in politics. After serving three terms as Washington County Attorney, interrupted by a voluntary enlistment in the Iowa National Guard for the Spanish American War, he desired to climb the political ladder. His next political objective was a seat in Congress. Unfortunately, in order to go to Congress from Washington County and the First Congressional District, it was first necessary to make peace with the Burlington railroad and its political representative, Joseph W. Blythe, who controlled the politics of the district and much of the state. ${ }^{8}$ Brookhart's insurgent nature, bordering on both courage and stubbornness, prevented him from making an accommodation with Blythe. With his future political advancement blocked by the railroads, Brookhart, by 1901, had become a political disciple of Albert B. Cummins who was the leader of the progressive forces in Iowa.

Brookhart's alliance with the progressive elements in the Cummins' camp produced little tangible results for his political career. In 1910 he was defeated in the Republican primary for the Congressional seat from the First Congressional District.

With his political future momentarily blocked, Brookhart turned to a new field, that of journalism. In December of 1911, he purchased the Washington County Press and began his career as a progressive editor. ${ }^{9}$ In his role as editor, Brookhart was con-

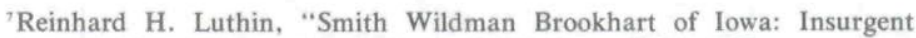
Agrarian Politician," Agricultural History, XXV (Oct., 1951), 187.

${ }^{8}$ Chester H. Rowell, "Brookhart, Howell, and 'Brother Charley' Bryan," World's Work, XLVI (Sept., 1923), 480.

${ }^{9}$ Brookhart's journalism career is a greatly ignored part of his life. The above discussion of this aspect of his life is taken from Johnston, "Smith Wildman Brookhart: Iowa's Last Populist," 43-76. 
cerned with what he believed to be a business oligarchy that was increasingly extending its influence over the government. As a corrective measure he proposed the extension of such political reforms as the direct primary, recall, initiative, and referendum. On some questions, though, Brookhart went much further than many of his progressive colleagues: he proposed government ownership of utilities, transportation, and communication facilities.

After World War I, Brookhart turned against his old progressive friend Albert Cummins. Cummins, as a United States senator, had sponsored the Esch-Cummins Act which returned the railroads to private ownership after the war with a very generous guarantee of return on their investments. Cummins' action alienated various railway labor groups; consequently they backed Brookhart as a candidate to oppose Cummins in the 1920 senatorial Republican primary. ${ }^{10}$ Brookhart, however, was unable to defeat his former political ally.

Despite his many political setbacks, Brookhart ran for the Senate in 1922, emphasizing economic issues in his campaign. $\mathrm{He}$ proposed cooperative marketing, repeal of the Esch-Cummins Act, changes in the Federal Reserve System which he contended was unfair to the farmer, a payment of a soldier's bonus, and in general he opposed the vested interests of wealth and what he termed "the non-partisan league of Wall Street." ${ }^{11}$ Brookhart won the election.

In December of 1922, the new Republican senator from Iowa arrived in Washington carrying with him a reputation for having a somewhat uncivilized character and personality. He was questioned by reporters about his middle name, Wildman. To this inquiry, Brookhart replied, "Wildman is a good name. It is my mother's name; it is English. But it is also notice to the standpatters that I am one Progressive who won't be tamed." ${ }^{12}$

Brookhart departed in the summer of 1923 for a tour of Europe. His journey, however, was to be quite different from those undertaken by other American politicians in 1923. The

${ }^{10}$ Jerry A. Neprash, The Brookhart Campaigns in Iowa, 1920-1926 (New York, 1932), 32.

"Des Moines Register. April 19, 1922.

${ }^{12}$ Ray Tucker and Frederick R. Barkley, Sons of the Wild Jackass (Boston, 1932), 344. 
purpose of the expedition, he said, was to bring the international rifle matches to America and to investigate the development of cooperatives in Europe. ${ }^{13} \mathrm{He}$ was accompanied by Dr. Alfred Pearce Dennis, a representative of the Commerce Department. Dennis traveled with Brookhart through fifteen European nations, but he was not allowed to enter Russia with the Senator as he was an official representative of the United States government which did not recognize Soviet Russia.

Dennis, in an account later published in the Saturday Evening Post, described the discomforts he suffered traveling with the Iowan. He complained that Brookhart did not "drink, dance, smoke, play cards, cuss, or tell shady stories." ${ }^{14}$ No traditional European tourist attractions such as palaces, cathedrals, or art galleries were visited by the Brookhart expedition. Brookhart explained that he was interested only in the future of Europe, and was content to let the "dead past bury its dead." 15 The Iowa senator traveled light, carrying only one small bag, and sought to curtail expenses. The Des Moines Register reported that other senators and congressmen visiting London in the summer of 1923 made reservations at the Carlton and Ritz, hotels with rates beginning at six dollars per day, while Brookhart stayed at the Y.M.C.A. where he was able to obtain a bed and breakfast for $\$ 1.25 .^{16}$ The idiosyncrasies of Brookhart, however, should not be allowed to obscure the fact that he believed he was engaged in an important fact-finding endeavor.

Brookhart was investigating the cooperative movement in Europe. No task could have been of more significance to the Iowan, as he maintained that cooperative marketing was the solution for the problems of the American farmer. Brookhart's faith in the cooperative system led him even beyond national borders. In the Senate, he declared, "The cooperative ownership, develop-

${ }^{13}$ Brookhart was an internationally known rifle expert, and had been an instructor in marksmanship for the United States Army in World War I. Brookhart's account of his 1923 European journey can be found in Smith Wildman Brookhart, "What I Really Saw and Learned in Europe in 1923," Saturday Evening Post, CCII (March 15, 1930), 23, 165-169.

${ }^{14}$ Alfred Pearce Dennis, "The European Education of Senator Brookhart," Saturday Evening Post. CCII (Dec. 14, 1929), 11.

${ }^{15}$ Brookhart, "What I Really Saw and Learned in Europe in 1923," Saturday Evening Post, CCII (March 15, 1930), 23.

${ }^{16}$ Des Moines Register, July 6, 1923. 
ment, and distribution of property is the natural and the rightful way for all the peoples of the world." ${ }^{17}$ Brookhart believed that the cooperative method was a basis upon which all the people of the world could engage in fair trade and equal association.

Even before his departure for Europe, Brookhart's admiration for the cooperative method had brought him into a political controversy. In February of 1923, he urged Congress to prohibit all interstate commerce not conducted under federal charter and the cooperative system. Irving Lenroot, senator from Wisconsin, labeled Brookhart's proposal as class legislation similar to that of the Russian Bolsheviks. Lenroot charged that not even Lenin would think of advocating such a plan. ${ }^{18}$ Lenroot's accusations were similiar to other charges hurled against the Iowa Senator after his return from Russia.

Meanwhile, in Europe Brookhart was finding new sources of inspiration for his faith in the cooperative idea. He discovered to his satisfaction that cooperatives in Europe were increasing in membership and prosperity. He was most impressed by the growth of the movement following World War I. While other businesses had receded after the war, cooperatives had tripled their volume of business. ${ }^{19}$ Cooperatives in Denmark particularly impressed Brookhart; he explained in an article for the Des Moines Register that farmers in Denmark were obtaining a square deal because they were organized. Organization enabled them to dominate the Danish parliament, and control their processing and purchasing through cooperatives. Brookhart drew what he considered important conclusions from the Danish situation for the American farmer.

With the economic power which such an organization would afford, the American farmers could end the beef trust, the sugar trust, the tobacco trust, the cement trust, and finally all of the great industrial trusts that are now levying such an extortionate toll of profits upon the American people. ${ }^{20}$

Exhilarated by his Scandinavian investigations, Brookhart left Dennis behind at the Russian border as he continued his journey into that land considered by the American government to

${ }^{17}$ Congressional Record, 69 Cong., 1 Sess. (1925-1926), LXVII, 3,279.

${ }^{18}$ New York Times, February 2, 1923.

${ }^{19}$ Brookhart, "What I Really Saw and Learned in Europe In 1923," Saturday Evening Post, CCII (March 15, 1930), 165.

${ }^{20}$ Des Moines Register, July 2, 1923. 
be an outlaw nation. Arriving in Moscow on June 11, Brookhart reported that the Russian wheat crop appeared to be very successful, and would have an important effect on the world grain markets. The Iowa Senator asserted, however, that the fertile Russians crops would not adversely affect the attitude of the American farmer toward Russia. He argued that if American farmers would follow the example of the Russian cooperatives, they would possess the means for gaining an equitable price for their grain in American markets without concerning themselves about the price of their exportable surplus. ${ }^{21}$ During his week-long visit, Brookhart became convinced of the progress of cooperation in Russia under Lenin. He commented, "The Soviet government has abandoned the communistic plan for that of the cooperative." ${ }_{22}$ The New York Times correspondent in Moscow insisted that Brookhart was naive in his perception of the cooperative movement in Russia, that Russian cooperatives were not operated by the peasants, but by "a bunch of Monopolistic Bolsheviki." ${ }^{23}$ Such polemics would have little appeal to a man who himself had been accused of Bolshevism for advocating cooperative enterprises.

On July 15, 1923, Brookhart returned to the United States, encouraged by what he had seen on the European continent. In response to questions from reporters, he stated that in his travels he had talked with the leaders of the common people and "upward" movements in Europe. In regard to Russia, Brookhart reported that he found Lenin and Trotsky to be able men. Undoubtedly, he surprised many Americans when he said that he would unhesitatingly recommend that the United States recognize Soviet Russia - to his mind the most stable government in the world, next to the United States. ${ }^{24}$

In July Brookhart met with Secretary of State Charles Evans Hughes to discuss his European trip; he reportedly urged the secretary to initiate American recognition of Russia. According to the New York Times of July 19, Brookhart argued for recognition on the grounds that the Soviet regime was stable, and that recognition would stabilize conditions in Europe and prevent fu-

${ }^{21}$ New York Times, June 12, 1923.

${ }^{22}$ Des Moines Register. July 18, 1923.

${ }^{23}$ New York Times, June 15, 1923.

${ }^{24}$ Des Moines Register, July 18, 1923. 
ture conflicts on that continent. This was basically the same reasoning expressed by William Borah, the most prominent senatorial advocate of Russian recognition. ${ }^{25}$ Brookhart's arguments, however, carried no more influence with the administration than those of Borah.

Diplomatic relations with Russia had been severed by the Wilson Administration following the Bolshevik Revolution in November of 1917. The basis of the American action was that the Bolsheviks had confiscated American property, advocated world revolution, and did not represent the majority of the Russian people. The following excerpt from the instructions of Secretary of State Robert Lansing to the American Ambassador in England captures very well the hostility expressed by the United States toward the Bolshevik Revolution.

The revulsion felt by the civilized world against the tyranny now holding

Russia in its power is shared by this government. This tyranny disregards all principles upon which dealings and relations between nations are founded and is not freely chosen by any considerable part of the people of Russia. ${ }^{26}$

The election of Warren Harding to the Presidency in 1920 produced no major change in American policy toward Russia. Following the unexpected death of President Harding on August 3, 1923, Calvin Coolidge quickly demonstrated that he planned no changes in the position formulated by Harding. In a press conference on August 31, Coolidge declared there would be no alterations in the American policy toward Russia. He described the American attitude as awaiting the establishment of a Russian government, that according to American standards, would warrant recognition. ${ }^{27}$

In view of the administration's policy, Brookhart's Russian initiative was rejected. Brookhart's activities also aroused the hostility of many Americans who had been concerned since 1917 with Russian threats of subversion. Many citizens, no doubt, were shocked to witness a United States senator extolling the virtues of

${ }^{25}$ Borah's basic line of reasoning on Russia can be found in the Congressional Record, 68 Cong., 1 Sess. (1923-1924), LXV, 583-584.

${ }^{20}$ Papers Relating to the Foreign Relations of the United States. 1920 (Washington, D.C., 1936), III, 462.

${ }^{27}$ Howard H. Quint and Robert H. Ferrell (eds.), The Talkative President: The Off-The-Record Press Conferences of Calvin Coolidge (Amherst, 1964), 255. 
Lenin and urging a change in the American policy toward the Soviets.

Brookhart was denounced by many press sources and leading citizens. The New York Times agreed with Brookhart's Iowa adversary, Senator Cummins, who said "If his powers were commensurate with his apparent desires, the Government would not last a fortnight." ${ }^{28}$ Samuel Gompers, whose American Federation of Labor was bitterly opposed to Russian recognition, maintained that no elements of a free government existed in Russia. Gompers found it hard to understand how Brookhart could comment favorably upon that forlorn country. ${ }^{29}$ Even the liberal New Republic, usually friendly to the Soviet government, argued that Hughes' negative reply to Brookhart's plea for recognition was reasonable. ${ }^{30}$

Brookhart's critics were also active in his home state of Iowa. B. F. Carroll, a former governor of the state, said that Brookhart was absurd in believing that he could understand the situation in Russia during a visit of such short duration. ${ }^{31}$ More serious charges were being made in Iowa against Brookhart by Alexander Schwartz, a Chautauqua speaker who claimed to be a former associate of Lenin. Schwartz felt that Brookhart had been deceived by Russian interpreters who allowed the senator to observe only conditions that would reflect favorably upon the Bolshevik regime. Brookhart had not been exposed to the actual situation in Russia. ${ }^{32}$ It is interesting to note that the accusations of Schwartz were later to be repeated in another period of extreme anti-communism. During the 1950s an editorial in the Annals of Iowa charged that Brookhart had been duped by the communists, and that through his activities Iowa had indirectly contributed to the spread of communist subversion in the United States. ${ }^{33}$

Smith Brookhart, however, was not intimidated by those who feared the Bolsheviks. He did not retreat from his advocation of

${ }^{28}$ New York Times, July 19, 1923.

${ }^{29}$ Nation's Business, XII (Feb., 1924), 9.

${ }^{30}$ New Republic XXXV (Aug. 1, 1923), 243.

${ }^{31}$ Des Moines Register, July 24, 1923.

${ }^{32}$ Ibid., July 26, 1923.

33"Brookhart's Interest in Russia," Annals of Iowa, XXXII (Jan., 1954), 230-232. 
recognizing Russia, and confronted the charges made against him. On July 28,1923 , he addressed a crowd of 5,000 members of the Iowa Farmers Union in Eldon, Iowa. He described the improved conditions he had observed in Russia, and replied to the allegation that he had been deceived by Russian interpreters. The senator insisted that he was allowed freedom of travel in Russia and mingled among the peasants without interference. His staff of interpreters consisted of an American relief worker, and several Russians who expressed to the senator that they were actually opposed to the Bolsheviks. ${ }^{34}$

Brookhart was not afraid to communicate his opinions to his constituency. Besides his speech at Eldon, he prepared an article on Russia for the state publication of the American Legion. In the article he argued that recognition would bring stability to Europe, and that the Soviet regime was certainly preferable to Czarism. Brookhart admitted that the Russians would have to make some changes in their governmental structure, but certainly this should not seem unusual to Americans, who had changed their government by nineteen amendments to the Constitution. ${ }^{35}$

Although Brookhart had been condemned by leading newspapers, a major labor leader, and a former governor, many people in Iowa did not seem to perceive Brookhart's diplomacy as a danger to American security. The Des Moines Register in July of 1923 printed many letters of support for Brookhart. Faith in Brookhart was expressed in simple terms in the following excerpt from one of the letters. "Smith Brookhart, our junior Senator, is a good man and honest. He went to Europe to study conditions, and he comes back to tell us what he thinks is best for the Senate to do." ${ }^{36}$ Another letter condemned former Governor Carroll for attacking Brookhart. While admitting that Brookhart did sometimes make mistakes, the writer concluded,“. . . he is honest and a man with a vision, with a single desire to help those in distress, and one who can see good in the common people." ${ }^{37}$ The letters supporting Brookhart do not express a knowledge of Russia or foreign affairs, but they do communicate a sense of trust in his

${ }^{34}$ Des Moines Register, July 29, 1923.

${ }^{35}$ New York Times, September 28, 1923.

${ }^{36}$ Des Moines Register, July 25, 1923.

${ }^{37}$ Ibid., July 26, 1923. 
honesty. They also reveal a sense of respect for Brookhart's concern with the common man.

The furor caused by Brookhart's statements on Russia soon faded as public attention turned toward the 1924 election. The senator was up for re-election in 1924 (his election in 1922 had been only for the unexpired term of Senator William Kenyon who had resigned). In the 1924 general election, Brookhart defeated his Democratic opponent by only 700 votes. However, the Senate, on an appeal, ruled against Brookhart. It was the contention of the Senate that many voters selecting the straight Republican ticket had, nevertheless, shown intent to vote for the Democratic senatorial candidate. The hostility of many voters and the Senate was not so much a result of Brookhart's Russian policy (which had not been a campaign issue), but his decision to bolt the Republican party and support Robert LaFollette for the Presidency. ${ }^{38}$

Brookhart's political career, however, had not ended. In 1926, campaigning on the issue of restoring agricultural prosperity to Iowa farmers, Brookhart was returned to the Senate. He renewed his crusade for a change in American policy toward Russia. While Brookhart had been out of public office, the negative attitude on the part of the American government toward recognition had not altered. Trade between the two nations had increased significantly. The total value of American exports to Russia had increased from $\$ 7,308,389$ in 1923 to $\$ 49,735,269$ in 1926 , yet there was basically no change in governmental policy, which still emphasized the threat of Russian subversion and propaganda. ${ }^{39}$ Secretary of State Frank Kellogg in a 1928 communication to the Republican National Committee reiterated the American fear of subversion.

It is the conviction of the Government of the United States that relations on a basis usual between friendly nations can not be established with a governmental entity which is the agency of a group who hold it as their mission to bring about the overthrow of the existing political, economic and social order throughout the world and who regulate their conduct towards other nations accordingly. ${ }^{40}$

The policy enunciated by Kellogg was criticized by Brookhart

${ }^{38}$ Neprash, Brookhart Campaigns in Iowa, 1920-1926, 48-52.

${ }^{30}$ Papers Relating to the Foreign Relations of the United States, 1928 (Washington, D.C., 1943), III, 825.

${ }^{40} \mathrm{Ibid} ., 822$. 
in a major senatorial address. The Iowa senator asserted that it was Americans, rather than Russians, who had historically, more frequently issued revolutionary propaganda. $\mathrm{He}$ argued that during the American Revolution statements were made that America would overthrow the monarchies of Europe. This type of propaganda has continued into the present in Fourth of July speeches, he asserted, and was evident in President Wilson's appeal to the German people to overthrow the Kaiser. Concerning the American claim that Russia should compensate Americans for property confiscated during the Russian Revolution, Brookhart declared that Russia possessed even stronger claims against the United States because of our intervention in Russia under President Wilson. Brookhart concluded that it was American aid and encouragement to counter-revolutionary forces that produced the bloody and destructive confrontations of the Russian Revolution. ${ }^{41}$

Brookhart claimed that conditions in Russia were improving. According to him, crime and graft had become almost nonexistent in Russia. The production of large industries, and the output of coal and oil had surpassed pre-war levels. These gains he said, were due to the growth of the cooperative movement in Russia. $\mathrm{He}$ noted that before the war Russian cooperatives had 650,000 shareholders, but in 1927 the number of shareholders had increased to 7,379,000. ${ }^{42}$ The Russian adoption of the cooperative idea had been the key to Russian economic progress, and Brookhart maintained that if America would follow the same practice, big business' control of the nation would be abolished. ${ }^{43}$

\# \#

Brookhart was defeated in a re-election bid in 1932 by an electorate demanding governmental action to relieve the Depression. Brookhart's opponent argued that the senator said much about the Depression, but instituted little action to alter the situation. Additionally, Brookhart's usual reputation for honesty was undermined by a charge of nepotism. In the midst of the Depression, issues such as recognition of Russia were dropped from the campaign. ${ }^{44}$

${ }^{41}$ Congressional Record, 70 Cong., 2 Sess. (1928-1929), LXX, 1,573.

${ }^{42}$ Ibid., 1,578. $\quad{ }^{43}$ Ibid., 1,574.

"4"“Playing Brookhart Out With a Steam Calliope," Literary Digest, CXIII (June 18, 1932), 5 . 
Following his defeat in 1932, Brookhart was again actively concerned with the problem of Russian relations. In May of 1933 he secured a position as a special adviser to the Agricultural Adjustment Administration of Franklin Roosevelt's New Deal. The Iowan was expected to seek an expanded market for surplus American agricultural products in Russia. Brookhart predicted that if adequate credits were extended to her, Russia would become an excellent consumer of American cotton, livestock, and manufactured articles. ${ }^{45}$ The Russian market envisioned by Brookhart did not materialize, however, as the expected credits were not extended.

Although he approved of the Roosevelt Administration's recognition of Russia in November of 1933, he withdrew from the administration because of his opposition to the New Deal program of crop reduction. The solution of the farm problem, according to Brookhart, was in controlling the profits of the middleman, and not the production of the farmer. He was unable to renew his political career after being defeated in the 1936 Iowa Republican senatorial primary. Crushed by this defeat, Brookhart retired to private law practice until his death in 1944. Why was Brookhart attracted to Russia? It is important to realize that his main concern during his senatorial career was the plight of Iowa farmers following the disastrous price decline that began in the summer of 1920 . Corn, the main staple of Iowa farmers, declined from a selling price of $\$ 1.20$ per bushel in 1919 to $\$ 0.47$ per bushel by the end of $1920 .{ }^{46}$ The price collapse of corn was not a temporary market dislocation. At the conclusion of the decade, corn remained at the low price of $\$ 0.70$ per bushel, with the average price per bushel from 1923 to 1927 resting at the low level of $\$ 0.67 .{ }^{47}$ Equally disastrous conditions beset the price of wheat. Iowa farmers received \$2 per bushel for wheat in 1919, but the price fell to $\$ 1.40$ per bushel in $1920 .^{48}$ By 1929 , the price of wheat had slumped to the extremely low level of $\$ 1.06$ per

${ }^{45}$ New York Times, May 8, 1933.

${ }^{40}$ United States Department of Agriculture, Yearbook of Agriculture, 1925 (Wąshington, D.C., 1926), 799.

${ }^{47}$ United States Department of Agriculture, Yearbook of Agriculture, 1930 (Washington, D.C., 1930), 629. 764.

${ }^{48}$ United States Department of Agriculture, Yearbook of Agriculture, 1925, 
bushel. ${ }^{49}$ The cause of this depression was simply that American agriculture had expanded to meet the needs of European markets during World War I, and after the war was over, European farmers returned to cultivating the soil, and Europe no longer needed to import large American grain surpluses. ${ }^{50}$

Brookhart may have thought that the recognition of Russia would provide a market for excess American grain. Although a logical interpretation, it does not coincide with the facts. Russia was not in fact a good market for American grain supplies. Brookhart, touring Russia in 1923, had predicted that Russian cooperatives would encourage greater production and prosperity for Russian agriculture. Since American corn exports to Russia fell from 3,392 bushels in 1923 to zero in 1924 there was some validity to his prediction. The same trend was evident in wheat transactions, as the amount of wheat exported to Russia declined from 85,274 bushels in 1923 to zero in $1924 .{ }^{51}$ Meanwhile, Russian corn and wheat production was increasing. The average production of corn in Russia during the pre-war years of 1909-1913 was 52,185,000 bushels, while under the Soviet government corn production had increased to $133,022,000$ bushels by $1927 .{ }^{52}$ A similar situation was evident in the Russian wheat crop. Production increased from a pre-war average of $607,828,000$ bushels in $1909-1913$ to a level of $751,920,000$ bushels in 1927. ${ }^{53}$

Smith Brookhart foresaw the Russian increase in production, yet he still urged diplomatic recognition. The reason must lie in his allegiance to the concept of cooperative marketing. He praised the cooperative idea in international terms. He urged American farmers to follow the example set by farmers and peasants in Denmark and Russia. He seemed to envision a world of producers trading equitably without interference of middlemen and businessmen in world trade. In Brookhart's thought, big business 600 .

${ }^{49}$ United States Department of Agriculture, Yearbook of Agriculture, 1930,

${ }^{50}$ James H. Shideler, Farm Crisis, $1919-1923$ (Berkeley, 1957), 10-19.

${ }^{51}$ United States Department of Agriculture, Yearbook of Agriculture, 1925. 1268-1269. 630.

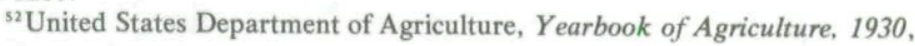
${ }^{53}$ Ibid., 603 , 
in the United States was behind the American refusal to recognize Russia. Business interests feared that if the common man in America learned of the successes of the Russian cooperative movement, then the cooperative idea would spread through the country. ${ }^{54}$

Brookhart's interest in Russia was based fundamentally upon the same ideas which Marian C. McKenna argues governed William Borah's sympathy for the Soviet government. McKenna says that Borah saw the Russian Revolution as an attempt by the lower class to increase its power and better its condition. ${ }^{55}$ Brookhart, too, viewed the Russian Revolution as a movement to benefit the common man. He considered the cooperative concept as a liberating force. Thus, he glorified the Russian experiment.

Russia is at work, and Russia under this government, however much you may condemn it, is coming back; and this property and this wealth as it is produced in Russia belongs to the people of Russia, and not to a few individuals who have acquired it through corporation organization, or through economic combinations or through special favors of laws of their country. ${ }^{56}$

This is the same dream that Brookhart had for the agricultural producers of Iowa, and indeed all the producers of the world.

Smith Brookhart's agrarian background apparently did not influence him toward isolationism. His attitude was an exception to the trend which linked agrarianism with isolationism. Although Brookhart did not support such formal international bodies as the League of Nations and the World Court, he felt a sense of common bond with agricultural producers throughout the world. He believed that the way to unite and free the common man was through the adoption of cooperative marketing on a global scale.

Brookhart did not seem to fit into the midwestern tradition of self-reliant agrarian individualism. He ascribed to utopian visions of a world of producers united by the cooperative movement. The Iowa senator, in common with many utopian thinkers, failed to formulate a political program to deal with the problems he defined. He believed that recognition of Russia would benefit the cooperative movement both there and in America, but he never adequately explained how this diplomatic process would foster cooperative development.

${ }^{54}$ Congressional Record, 70 Cong., 2 Sess. (1928-1929), LXX, 1,574.

${ }^{55}$ Marian C. McKenna, Borah (Ann Arbor, Michigan, 1961), 287.

${ }^{56}$ Congressional Record, 70 Cong., 2 Sess. (1928-1929), LXX, 1,575. 
Copyright of Annals of Iowa is the property of State of Iowa, by \& through the State Historical Society of Iowa and its content may not be copied or emailed to multiple sites or posted to a listserv without the copyright holder's express written permission. However, users may print, download, or email articles for individual use. 